\title{
Thermal conditioning in the broiler production: challenges and possibilities
}

\author{
Nágela Maria Henrique Mascarenhas - Antonio Nelson Lima da Costa • \\ Maria Leidiane Lima Pereira - Ana Carolina Alves de Caldas • \\ Luanna Figueirêdo Batista • Evyla Layssa Gonçalves
}

\author{
NMH Mascarenhas (Corresponding author) - ACA Caldas * \\ LF Batista - EL Gonçalves \\ Universidade Federal de Campina Grande (UFCG), Campus \\ de Patos, Caixa Postal 64, 58708-110, Patos, PB, Brazil. \\ email: eng.nagelamaria@gmail.com
}

\author{
ANL Costa - MLL Pereira \\ Universidade Federal do Cariri (UFCA), Campus Crato, s/n, \\ Rua Icaro de Sousa Moreira, Barro Branco, Crato, CE, Brazil.
}

Received: August 30, 2017 • Revised: January 20, 2018 • Accepted: January 20, 2018

\begin{abstract}
With the introduction of new technologies that lead to the development of new systems of poultry breeding, have been promoted to the animals better thermal comfort conditions. This lessens the great challenge for industrial poultry, with regard to aviary constructions, resulting in increased productivity. It is known that an animal in heat stress condition presents lower productive performance. A lower feed conversion caused by decreased feed intake is the main cause. Multidisciplinary studies have been developed seeking the deepening the needs and possibilities already available about these new systems. With this, this review seeks to approach in a didactic and simplified way the planning and construction of aviary sheds aiming to provide an suitable thermal conditioning for broiler accommodation.
\end{abstract}

Keywords: bioclimatology, ambience, poultry industry, animal welfare

\section{Introduction}

In recent years broiler meat is the animal protein fastest growing in the Brazil, with the prospect of exceeding current production from 13,028 million tons to 20,332 million tons, showing a growth of $56.1 \%$ in ten years (Avicultura Industrial 2012).

However, productive performance of the broilers can be affected by the environment of intensive breeding systems, which can have direct influence on thermal comfort conditions and animal welfare, which causes a setback in regulation of the thermal equilibrium inside facilities. This being observed in the behavioral expressions of the animals. Thus, the semiintensive breeding system, considered as alternative, allows birds access to grazing areas, which when compared to the intensive breeding system results in particular differences in the meat quality (Nazareno et al 2009).

Any animal that is homeothermic is susceptible to the innumerable environmental variations. Thus, animals exposed outside the thermal comfort range require adjustments, be they behavioral, physiological or anatomical, to adapt to new environmental conditions (Welker et al 2008). The animal productivity is directly influenced by environment, by changing the heat exchange and dissipation, also by altering the fractionation of the energy available in diet and weight gain (Zanusso et al 1999).

Oliveira et al (2006) says that relative humidity and air temperature are thermal factors that directly affect broilers, compromising their homeothermic regulation, a function obtined through sensible and latent processes of heat loss. The relative humidity is inversely proportional to the birds' ability to withstand heat. Therefore, the greater the air humidity, greater the difficulty in removing the internal heat through the airways, which consequently leads to an increase in respiratory rate. For these reasons, birds' performance is compromised, since perform all this process in the one of homeothermic regulating, causing physiological changes.

Thus, according to Zanusso et al (1999), thermal comfort should be provided to birds, so that the nutrients consumed in diet can be better utilized, leading to an increase in the weight gain, which is one of the main goals of modern poultry farming. This is because the environment also influences the feed intake, both in cold and heat situations, since it adapts the nutritional requirement the environment in which they are.

In this way, the present review sought to approach, in a simplified and didactic way, planning in the preparation of poultry sheds, different materials and different construction techniques available to poultry industry, in what contemplates the Brazilian poultry industry, aiming to provide a suitable thermal condition for poultry housing.

\section{Relationship between broilers and their environment}

As already demonstrated, the animal that is under heat stress tends to change its metabolic functions to remain in its 
thermoneutrality zone. Studies about thermal comfort have been developed with the purpose of demonstrating the losses that thermal stress, whether cold or heat, has caused on the animals, in the present study, broilers.

Broilers need precise thermal conditions to keep producing steadily at favorable levels. Each of these animals has a adaptation power that gives it its survival within the adversity limits. According to Abreu and Abreu (2011), birds being homeothermic animals, capable of regulating their body temperature, it is known that in the face of the energy ingested in the dieta, about $80 \%$ of this energy is used to maintain body temperature and $20 \%$ remaining energy are used only for productive performance.

According to Furtado et al (2006), when the animal is in a heat stress state, it reduces the feed intake, begins to expend energy in the heat dissipation process, which in normal conditions, this energy would be used in production. With these data we see the importance of keeping these animals within thermal comfort zone. Only within certain limits of the ambient temperature, the homeostasis mechanism is efficient, so it is important that facilities are at temperatures close to the comfort conditions (Table 2).

Table 1, below, shows the practical values of lower critical temperature (LCT), thermal comfort zone (TCZ) and upper critical temperature (UCT) in the birds' life stages.
Table 1 Lower critical temperature (LCT), thermal comfort zone (TCZ) and upper critical temperature (UCT), according to birds' life stage.

\begin{tabular}{lccc}
\hline Life stage & LCT $\left({ }^{\circ} \mathrm{C}\right)$ & TCZ $\left({ }^{\circ} \mathrm{C}\right)$ & UCT $\left({ }^{\circ} \mathrm{C}\right)$ \\
\hline Newborn & 34 & 35 & 39 \\
Adult & 15 & 18 a 28 & 32 \\
\hline
\end{tabular}

Source: Curtis (1983).

In order to minimize the effects that the heat stress causes in these animals, some methods have been developed and tested. Thermal conditioning methods that leave the environment in which the animals are inserted comfortable for their development. Thermal exchanges between birds and environment in the thermal balance is continuous, even so, only when the ambient temperature is inside thermal comfort zone, this mechanism is considered efficient. The birds' internal heat that is exceeded must be eliminated so that their temperature is maintained constant. If by chance the heat produced is greater than the heat dissipated, the body temperature will increase, and when it reaches a certain temperature (hyperthermia level), it can die by prostration (Abreu and Abreu 2011).

Table 2 Ideal values of ambient temperature and air humidity, depending on the age of the birds.

\begin{tabular}{lcc}
\hline Age (weeks) & Air temperature $\left({ }^{\circ} \mathrm{C}\right)$ & Relative humidity $(\%)$ \\
\hline 1 & $32-35$ & $60-70$ \\
2 & $29-32$ & $60-70$ \\
3 & $26-29$ & $60-70$ \\
4 & $23-26$ & $60-70$ \\
5 & $20-23$ & $60-70$ \\
6 & 20 & $60-70$ \\
7 & 20 & $60-70$ \\
\hline
\end{tabular}

\section{Bioclimatic diagnostic}

Due to difference in climate of each locality, seeking to adapt poultry facilities to their realities means not only constructing spaces, but also creating them in a way that adjusts the animal needs that will occupy it, allowing them thermal comfort conditions. Therefore, poultry facilities projects should minimize the discomfort caused by adverse weather, whether cold or hot, and also provide comfortable environments with air circulation that does not affect productivity (Tinôco 2001). The main meteorological elements that directly interfere the broilers' productive performance are the air temperature, relative humidity and the radiation heat load. One of the main causes of thermal discomfort that can be cited is also solar radiation, especially in Brazil, since the vast majority of the facilities built are open.
Furtado et al (2003) says that, from the bioclimatic view point, the roof, by their covering materials, is one of the main elements that influence the radiant heat load. Also it is one of the most significant building components of facilities since it is concluded that the heat flow through roof is the main cause of the discomfort inside the sheds.

However, climatic adversities found in Brazil do not allow a single shed to serve as a single model for all country regions, which makes it necessary to know the region climate where the poultry activity will be developed, taking into consideration that these facilities must offer thermal comfort, according to the birds requirements. 


\section{Basic ambience}

For the construction of any poultry house requires a thorough study of the geographic region climate or place where it will be installed. Thus, it is possible to construct facilities that are capable of minimizing the thermal discomfort effects. As the problem of Brazil are hot climates regions, what should be proposed are facilities that can reverse the high temperatures effects, leaving the thermal environment comfortable.

For Abreu and Abreu (2011), the main primary traits to be taken into account in the poultry facilities construction are: location, orientation, heigth, eaves, dimensions, closings, louver, roof, among others, besides the material characteristics which will be used in the sheds, which also allow the natural thermal conditioning. According to Sarmento et al (2005), ventilation is necessary for the humidity elimination from the internal environment of the facilities, caused by the water elimination through birds' respiration and their excreta, as well as to allow the air renewal and the odors elimination.

\section{Thermal conditioning challenges}

One of the greatest challenges involving efficient thermal conditioning is the negative pressure, ie, sealing and total insulation of the shed. This making internal conditions of facilities totally independent of the external environment, generating a environment that presents temperature controlled. In this case, occurs maximum comfort demanded by broilers, since their productive performance is affected by the environmental conditions (Tinôco 2001).

To be efficient it is necessary that materials are protected, and isolated, besides the fence that is the main responsible for the air flow inside shed. Maintaining the wellsealed environment is of extreme importance for a efficient thermal conditioning (Abreu and Abreu 2011). However, if the sealing system is not in accordance with the calculation, it may have negative consequences such as environment humidification, generating a high harmful gas concentrations ( $\mathrm{NH} 3, \mathrm{CO}$ and $\mathrm{CO} 2$ ), which is unsuitable for broilers health and performance. The interest in gas production concerns not only the birds health, but also workers who spend between 4 and 8 hours in this environment

Another challenge to be highlighted and discussed is light program, which for long periods was studied with the purpose of regulating the feed intake increase, aiming at a broilers' suitable growth, without compromising feed conversion. This practice was more prominent in summer season, when broilers are stimulated to feed more at night shift, when temperatures are low. However, there is still a need for further studies on this subject, where new conditioning systems are highlighted and can generate more information about poultry farming (Cordeiro et al 2010).

\section{Final Considerations}

Although of the Brazil to be the country with greater relevant informations on thermal conditioning of poultry facilities in tropical climate, there is still a lack of information about energy expenditure, systems efficiency (heating or cooling), animal welfare and air quality.

So, given these facts, it is clear the need for a more further study on the thermal conditioning in poultry. It is necessary to better explain the possibilities that already exist for improvement of the breeding systems, independently of the technology level used. Multidisciplinary studies should be carried out, where the environment becomes the basis of these studies.

In this way, when thermal comfort conditions are offered to animals, a greater productive return to the production system is observed. Previous knowledge about the animal physiology and behavior is also fundamental to decide on the thermal conditioning type to be used in the productive system, besides the know of the region climate. And finally, it is essential to have skilled labor that, in front of all this technology, must be necessarily specialized.

\section{References}

Abreu VMN, De Abreu PG (2011) Os desafios da ambiência sobre os sistemas de aves o Brasil. Revista Brasileira de Zootecnia 40:114.

Avicultura Industrial (2012) AveSui: Produção de frango é a que mais deve crescer no Brasil na próxima década. http://www.aviculturaindustrial.com.br/noticia/avesui-producao-defrango-e-a-que-mais-deve-crescer-no-brasil-na-proximadecada/20120402164314_g_456. Acessado em: 11 junho 2015.

Cordeiro MB, Tinôco IFF, Da Silva JN, Vigoderis RB, Pinto FAC, Cecon PR (2010) Conforto térmico e desempenho de pintos de corte submetidos a diferentes sistemas de aquecimento no período de inverno. Revista Brasileira de Zootecnia 39:217-224.

Curtis SE (1983) Environmental management in animal agriculture. Iowa State University Press, Ames.

Furtado DA, Azevedo PV, Tinôco IFF (2003) Análise do conforto térmico em galpões avícolas com diferentes sistemas de acondicionamento. Revista Brasileira de Engenharia Agrícola e Ambiental 7:559-564.

Furtado DA, Dantas RT, Do Nascimento JWB, Santos JT, Costa FG (2006) Efeitos de diferentes sistemas de acondicionamento ambiente sobre o desempenho produtivo de frangos de corte. Revista Brasileira de Engenharia Agrícola e Ambiental 10:484-489.

Nazareno AC, Pandorfi H, Almeida GLP, Giongo PR, Pedrosa EMR, Guiselini C (2009) Avaliação do conforto térmico e desempenho de frangos de corte sob regime de criação diferenciado. Revista Brasileira Engenharia Agrícola Ambiental 13:802-808.

De Oliveira RFM, Donzele JL, De Abreu MLT, Ferreira RA, Vaz RGMV, Cella PS (2006) Efeitos da temperatura e da umidade relativa sobre o desempenho e o rendimento de cortes nobres de frangos de 
corte de 1 a 49 dias de idade. Revista Brasileira de Zootecnia 35:797803.

Tinôco IFF (2001) Avicultura Industrial: Novos Conceitos de Materiais, Concepções e Técnicas Construtivas Disponíveis para Galpões Avícolas Brasileiros. Revista Brasileira de Ciência Avícola 3:806-809.

Sarmento LGV, Dantas RT, Furtado DA, Do Nascimento JWB, Da Silva JHV (2005) Efeito da pintura externa do telhado sobre o ambiente climático e o desempenho de frangos de corte. Revista Agropecuária Técnica 26:117-122.

Zanusso JT, De Oliveira RFM, Donzele JL, Ferreira RA, Rostagno HS, Euclydes RF, Valerio SR (1999) Níveis de Energia Metabolizável para Frangos de Corte de 1 a 21 Dias de Idade Mantidos em Ambiente de Conforto Térmico. Revista Brasileira de Zootecnia 28:1068-1074.

Welker JS, Rosa AP, De Moura DJ, Machado LP, Catelan F, Uttpatel $\mathrm{R}$ (2008) Temperatura corporal de frangos de corte em diferentes sistemas de climatização. Revista Brasileira de Zootecnia 37:14631467. 